\title{
Experimental Analysis of Corrosive Impact of Oxidizing and Non-oxidizing Environment on Sensitized Welded and Unwelded Samples of AISI 316
}

\author{
Silas Ezedinma Agbokwor ${ }^{1,}$, , Daniel Oray Nnamdi Obikwelu², Simeon Ikechukwu Neife ${ }^{2}$ \\ ${ }^{1}$ Department of Mechanical Engineering, Faculty of Engineering, University of Nigeria Nsukka (UNN), Nsukka, Nigeria \\ ${ }^{2}$ Department of Metallurgical and Materials Engineering, Faculty of Engineering, University of Nigeria Nsukka (UNN), Nsukka, Nigeria
}

Email address:

chideraogo@yahoo.com (S. E. Agbokwor)

${ }^{*}$ Corresponding author

To cite this article:

Silas Ezedinma Agbokwor, Daniel Oray Nnamdi Obikwelu, Simeon Ikechukwu Neife. Experimental Analysis of Corrosive Impact of Oxidizing and Non-oxidizing Environment on Sensitized Welded and Unwelded Samples of AISI 316. American Journal of Mechanical and Materials Engineering. Vol. 3, No. 3, 2019, pp. 61-69. doi: 10.11648/j.ajmme.20190303.13

Received: September 11, 2019; Accepted: October 9, 2019; Published: October 28, 2019

\begin{abstract}
An experimental analysis was carried out to investigate the corrosivity of sensitized welded and unwelded austenitic stainless steel AISI 316, in oxidizing $\left(\mathrm{H}_{2} \mathrm{SO}_{4}\right)$ and non-oxidizing (HCL) media. The selected samples were cut into several equal pieces. To induce sensitization, the samples were heated and soaked at $750^{\circ} \mathrm{C}$ at different soaking time intervals such as 30 minutes, 60 minutes, 180minutes, 300 minutes and 600 minutes followed by water quenching. The sensitized welded and unwelded samples each were subjected to immersion duration test in the oxidizing and non-oxidizing media for 5 , $10,15,20,25,30,35,40,45$, and 50 minutes, respectively. It was concluded from the results obtained that corrosion rate of welded and unwelded decreases as soaking time and immersion duration increases at constant soaking temperature, in nonoxidizing medium of hydroChloric acid ( $\mathrm{HCL})$; but the decrease in corrosion rate is more in the unwelded samples. In the oxidizing medium of sulphoric acid $\left(\mathrm{H}_{2} \mathrm{SO}_{4}\right)$; corrosion rate of the samples decreased as immersion duration/soaking time increases. However, the welded samples experienced erratic behaviour in the oxidizing medium, having a lower corrosion rate than their unwelded counterpart surprisingly, at immersion duration between 25-50 minutes as soaking time increases at constant soaking temperature of $750^{\circ} \mathrm{C}$.
\end{abstract}

Keywords: Austenitic Stainless Steel AISI 316, Corrosion Rate, Sensitization, Immersion Duration, Oxidizing and Non-oxidizing Media, Soaking Temperature, Soaking Time, Welded and Unwelded

\section{Introduction}

Corrosion of materials [2] is the most common and most important failure mechanism in industry. Stainless steels retain its special qualities in structures because of their strength, stiffness, toughness and tolerance at high temperatures [3]. Their usage in Catalytic Reformer Unit, Reactor Scallops, Vacuum Distillation Unit, Heat Tubes at Port Harcourt Refinery; process and utility areas of Mobil producing Nigeria unlimited and Chevron Escravos gas to liquid plants all in Nigeria, is a demonstration of their importance [1]. They are widely used in harsh oil and gas production environments. Austenitic stainless steel is widely used in caustic environments [4-9].
These steels usually in welded form to achieve the desired design, have been observed to experience various debilitating forms of localized corrosion like pitting, crevice and stress corrosion cracking [10-16], when exposed to chloride containing solution environments; leading to loss of millions of dollars each year [17, 18]. Although one of the main reasons why stainless steels are used is corrosion resistance; they do suffer from certain types of corrosion in some environments; for instance, austenitic stainless steel is sensitive to chloride-induced stress-corrosion cracking (SCC) $[19,20]$. Therefore, care must be taken to select a grade which will be suitable for certain type of application [21]. Time, temperature and environment therefore, significantly influences this unusual complex/sensitized microstructure of 
the steels and hence its properties [22].

The harsh acidic environment at the sensitized regions can be too aggressive to allow passivity to be maintained by; being too reducing, in some acidic media (e.g. Hydrochloric acid); so that passivating species cannot form [23] and being too oxidizing (e.g. Hot dilute nitric acid or $\mathrm{H} 2 \mathrm{SO} 4$ ) and thus make oxidized species that normally affect passivity unstable. Weld decay has been observed to be common in sensitized stainless steel structures [24].

These unavoidable circumstances results in heterogeneous microstructure with small amount of delta ferrite and significant segregation of major as well as minor alloying elements at the phase interfaces. This steel alloys usually have many constituent elements and many thermodynamically possible phases, complicated with the facts that none of these possible phases are necessarily uniform in their composition. Interestingly, it is the composition of the alloy in contact with the specific environment at any microscopic point that determines the corrosion resistance of that particular point. It is not unusual therefore, that one can find out erratic behaviour of some alloys, especially at the steel weldment in a particular environment; the alloy displaying both resistance and susceptibility to corrosive attack.

This research was set out to study the influence of environments on the corrosivity of sensitized welded and unwelded stainless steels \{AISI 316\}; to assist in addressing some of the worrisome and disturbing cases despite numerous researches. The inferences from the experimental results could assist in establishing a relationship on various factors (oxidizing and non-oxidizing environment, alloy composition, microstructure, Temperature, immersion Time, etc). This understanding would assist in mitigating the menace of corrosion in a susceptible environment as low as reasonably practicable.

\section{Methodology}

\subsection{Materials}

AISI 316 stainless steel was selected for this investigation. The sample is a commercial pure sample and was available in form of pipes and was collected from the ware house of Port Harcourt Refinery Company Ltd, Alese Eleme, Port Harcourt, Rivers State-Nigeria.

\subsection{Equipments}

Equipments used for the study included the following: Welding machines, Grinding machines, Cutting machines, Universal milling machine, Manual hand Hacksaw with blade, heat treatment furnace, Oxford instrument XRF spectrometer model X-Met 7000 with a serial number 711150, Crown technology inc. CT 1000 corrosion meter [capable of reading corrosion rate], Epoxy Resin Ring, Emery Paper.

\subsection{Experimentation}

\subsubsection{Chemical Composition}

The chemical composition of the selected welded and unwelded steel samples were determined at Turret Engineering Services Ltd., Port Harcourt using an Oxford instrument XRF spectrometer model X-Met 7000 with serial number 711150 . The detailed chemical compositions of the samples are as shown in figures I and II below.
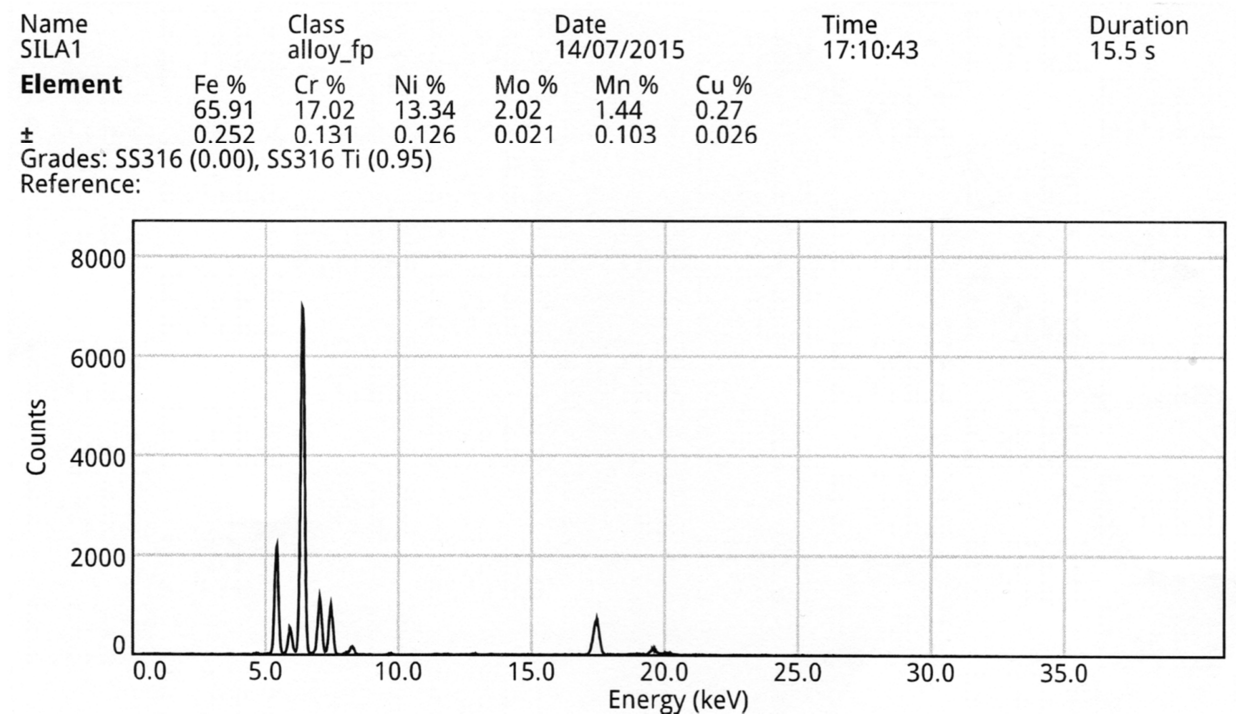

Figure 1. Chemical composition of Austenitic Stainless Steel AISI 316 (Unwelded sample).

\begin{tabular}{|c|c|c|c|c|c|c|c|c|c|}
\hline $\begin{array}{l}\text { Name } \\
\text { SILA1 W } \\
\text { Element }\end{array}$ & \multicolumn{3}{|c|}{$\begin{array}{l}\text { Class } \\
\text { alloy_fp }\end{array}$} & \multicolumn{3}{|c|}{$\begin{array}{l}\text { Date } \\
14 / 07 / 2015\end{array}$} & \multicolumn{2}{|c|}{$\begin{array}{l}\text { Time } \\
\text { 17:12:12 }\end{array}$} & \multirow[t]{2}{*}{$\begin{array}{l}\text { Duration } \\
15.5 \mathrm{~s}\end{array}$} \\
\hline $\begin{array}{l}\text { Element } \\
\pm\end{array}$ & $\begin{array}{l}\mathrm{Fe} \% \\
65.69 \\
0.240\end{array}$ & $\begin{array}{l}\mathrm{Cr} \% \\
17.41 \\
0.126\end{array}$ & $\begin{array}{l}\mathrm{Ni} \% \\
12.57 \\
0.116\end{array}$ & $\begin{array}{l}\text { Mo \% } \\
2.13 \\
0.020\end{array}$ & $\begin{array}{l}\mathrm{Mn} \% \\
1.62 \\
0.101\end{array}$ & $\begin{array}{l}\mathrm{Cu} \% \\
0.30 \\
0.023\end{array}$ & $\begin{array}{l}\text { Co \% } \\
0.17 \\
0.040\end{array}$ & $\begin{array}{l}\mathrm{Ti} \% \\
0.10 \\
0.033\end{array}$ & \\
\hline
\end{tabular}




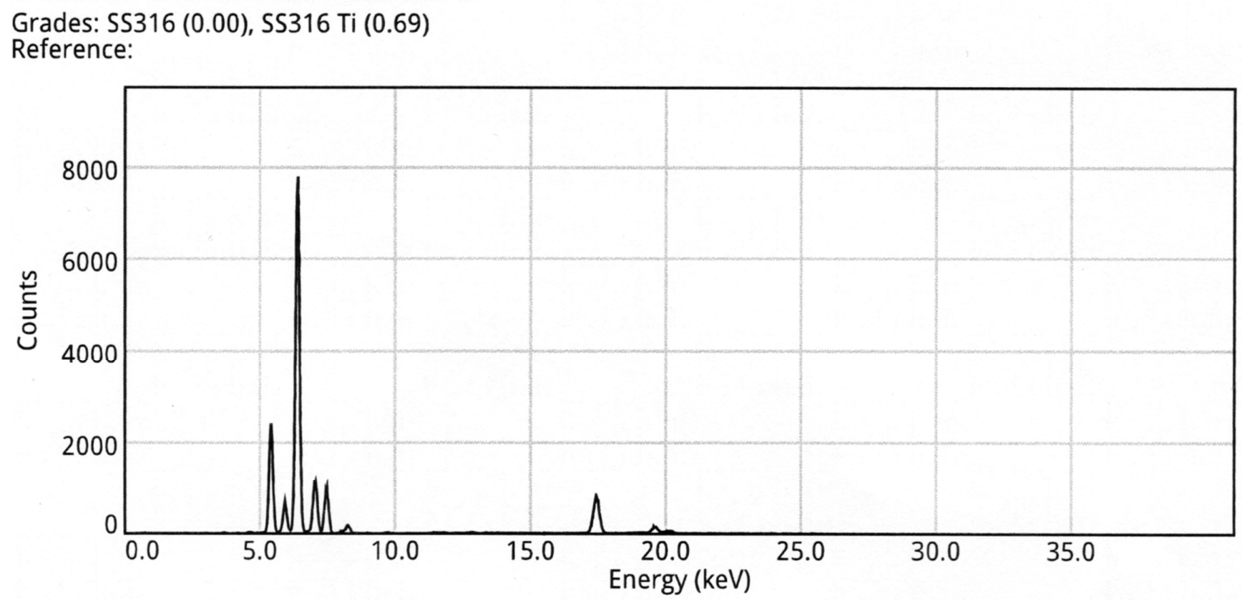

Figure 2. Chemical composition of Austenitic Stainless Steel (AISI 316) Weldment.

\subsubsection{Heat Treatment}

The chosen grade of stainless steel was procured and welded; following all necessary Global Practices/standards and code requirements. The weldment and the unwelded samples were cut to sizes and subjected to heat treatment using solution annealing for 1 hour at $1000^{\circ} \mathrm{C}$, followed by quenching in water to dissolve the precipitate phases, if any.

The samples were then prepared by cutting into several equal pieces. To induce sensitization, the samples were soaking at $750^{\circ} \mathrm{C}$ at different time intervals such as 30 minutes, 60 minutes, 180minutes, 300 minutes, 500 minutes, 400 minutes and 600 minutes followed by water quenching. This type of heat treatment schedule by varying the holding times was suggested by Ghosh et al.

Consequently, corrosion study was carried out on the prepared samples from the weldment and the unwelded samples of the sensitized steels; by immersion at different time intervals in corrosive media $\{\mathrm{HCL}=$ non-oxidizing and $\mathrm{H}_{2} \mathrm{SO}_{4}=$ oxidizing $\left\{\mathrm{H}_{2} \mathrm{SO}_{4}\right\}$. The tabulated results and graphical representations/discussions are as shown in below.

\section{Results/Graphical Representations}

Table 1. The results and their graphical representations are as shown below \{Tables 1-6 and Figures 3-8\}. Corrosion rate(COR) of unwelded AISI 316 samples $\{1 \mathrm{~A}, 2 \mathrm{~A}, 3 \mathrm{~A}, 4 \mathrm{~A}, 5 \mathrm{~A}, 6 \mathrm{~A}, 7 \mathrm{~A}\}$, soaked at $750^{\circ} \mathrm{C}$ at variable soaking time of $30,60,180,300,400,500$ and 600 minutes respectively and immersed in non-oxidizing medium (HCL) at variable immersion duration.

\begin{tabular}{|c|c|c|c|c|c|c|c|}
\hline \multirow{2}{*}{$\begin{array}{l}\text { Immersion duration } \\
\text { (Minutes) }\end{array}$} & $1 \mathrm{~A}$ & $2 A$ & $\mathbf{3 A}$ & $4 \mathrm{~A}$ & $5 \mathbf{A}$ & $6 A$ & $7 \mathrm{~A}$ \\
\hline & COR (mpy) & COR (mpy) & COR (mpy) & COR (mpy) & COR (mpy) & COR (mpy) & COR (mpy) \\
\hline 5 & 3.60 & 3.53 & 3.20 & 19.45 & 9.50 & 7.74 & 7.72 \\
\hline 10 & 3.09 & 3.30 & 3.17 & 7.90 & 6.98 & 6.95 & 3.61 \\
\hline 15 & 4.41 & 2.86 & 2.86 & 2.72 & 3.45 & 3.06 & 3.05 \\
\hline 20 & 3.33 & 2.69 & 2.90 & 4.04 & 3.54 & 3.19 & 3.57 \\
\hline 25 & 2.78 & 3.09 & 3.32 & 3.13 & 3.33 & 3.14 & 3.04 \\
\hline 30 & 2.77 & 2.82 & 3.10 & 4.60 & 1.28 & 4.28 & 3.45 \\
\hline 40 & 2.88 & 2.71 & 3.06 & 2.94 & 2.29 & 2.57 & 2.20 \\
\hline 45 & 2.80 & 2.73 & 2.54 & 2.55 & 2.77 & 3.24 & 3.71 \\
\hline 50 & 2.39 & 2.56 & 2.66 & 3.28 & 2.63 & 2.10 & 2.14\{ \\
\hline
\end{tabular}

Table 2. Corrosion rate(COR) of welded AISI 316 samples $\{1 \mathrm{AW}, 2 \mathrm{AW}, 3 \mathrm{AW}, 4 \mathrm{AW}, 5 \mathrm{AW}, 6 \mathrm{AW}, 7 \mathrm{AW}\}$, soaked at $750^{\circ} \mathrm{C}$ at variable soaking time of $30,60,180$, 300, 400, 500 and 600 minutes respectively and immersed in non-oxidizing medium (HCL) at variable immersion duration.

\begin{tabular}{|c|c|c|c|c|c|c|c|}
\hline \multirow{2}{*}{$\begin{array}{l}\text { Immersion } \\
\text { duration (Minutes) }\end{array}$} & $1 \mathrm{AW}$ & $2 \mathrm{AW}$ & 3AW & 4AW & 5AW & 6AW & 7AW \\
\hline & COR (mpy) & COR (mpy) & COR (mpy) & COR (mpy) & COR (mpy) & COR (mpy) & COR (mpy) \\
\hline 5 & 9.51 & 16.17 & 9.69 & 7.70 & 4.97 & 5.47 & 5.13 \\
\hline 10 & 8.56 & 9.03 & 8.92 & 4.98 & 5.17 & 5.33 & 5.20 \\
\hline 15 & 7.79 & 8.07 & 9.17 & 5.55 & 5.00 & 5.17 & 5.44 \\
\hline 20 & 8.27 & 8.33 & 7.27 & 5.19 & 5.03 & 4.97 & 4.74 \\
\hline 25 & 7.31 & 7.36 & 8.31 & 4.56 & 4.70 & 4.43 & 2.12 \\
\hline 30 & 6.91 & 7.23 & 6.41 & 4.45 & 4.72 & 4.96 & 4.11 \\
\hline 40 & 5.92 & 6.60 & 5.98 & 3.61 & 3.43 & 3.55 & 3.50 \\
\hline 45 & 5.52 & 5.47 & 5.41 & 3.36 & 3.28 & 3.42 & 3.33 \\
\hline 50 & 5.19 & 4.88 & 4.63 & 3.30 & 3.27 & 3.56 & 3.59 \\
\hline
\end{tabular}




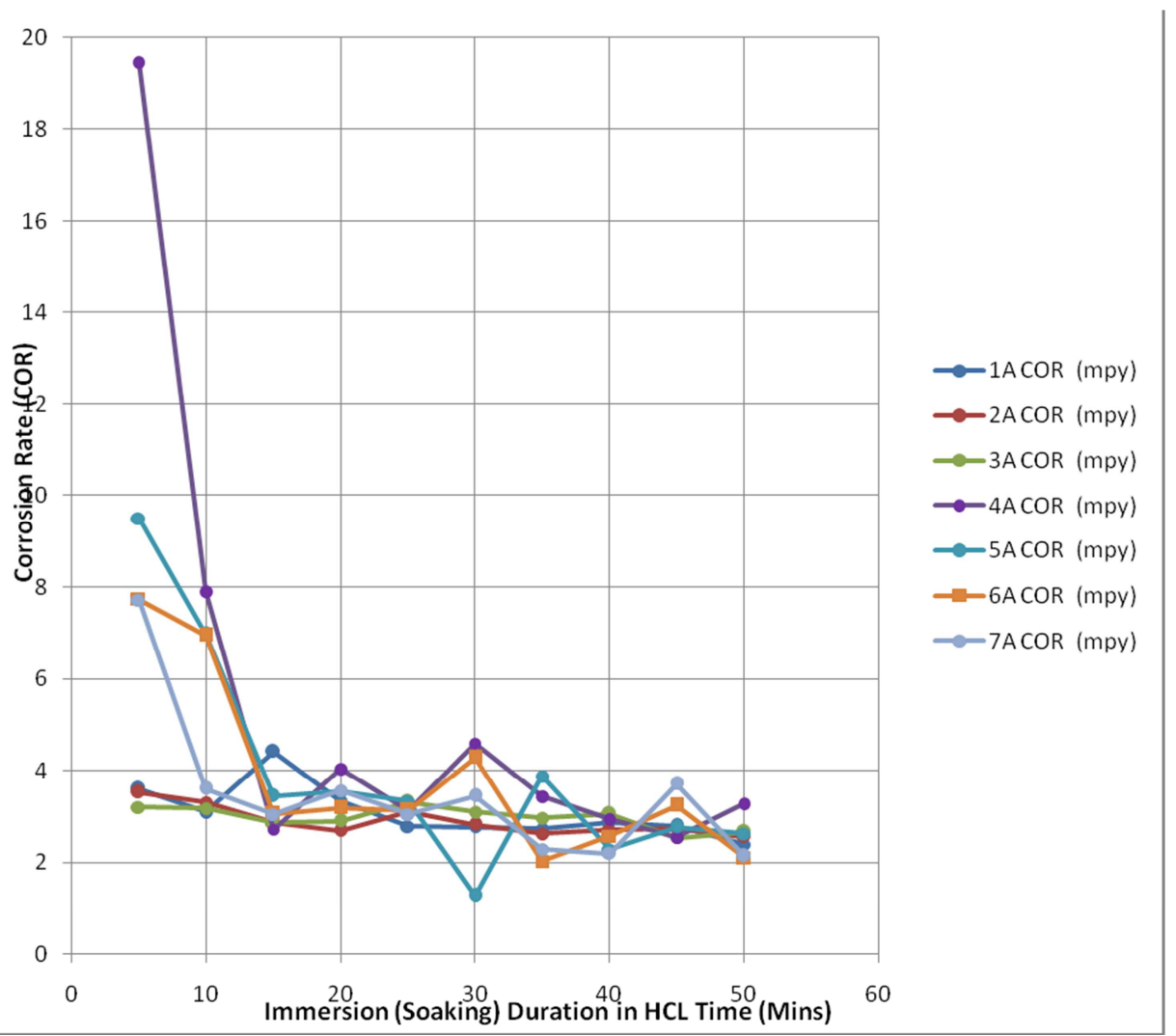

Figure 3. Graphical relationship of immersion duration in non-oxidizing medium (HCL) versus corrosion rate (COR) for various samples in table 1.

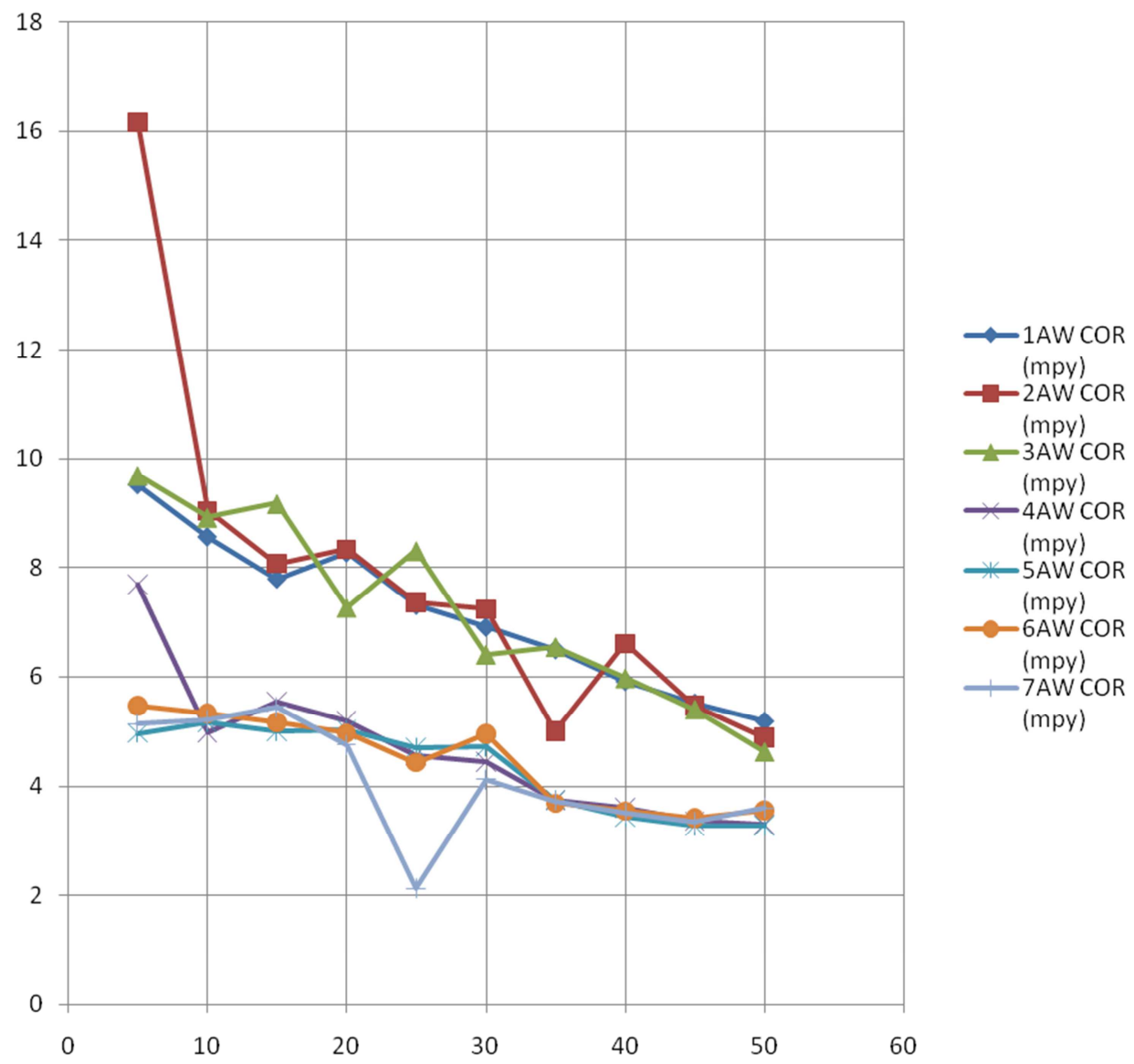

Figure 4. Graphical relationship of immersion duration in non-oxidizing medium (HCL) versus corrosion rate (COR) for various samples in table 2. 
Table 3. Corrosion rate (COR) of unwelded AISI 316 samples $\{8 \mathrm{~A}, 9 \mathrm{~A}, 10 \mathrm{~A}, 11 \mathrm{~A}, 12 \mathrm{~A}, 13 \mathrm{~A}, 14 \mathrm{~A}\}$, soaked at $750^{\circ} \mathrm{C}$ at variable soaking time of 30 , 60 , 180 , 300, 400, 500 and 600 minutes respectively and immersed in oxidizing medium $\{$ H2SO4\} at variable immersion duration.

\begin{tabular}{llllllll}
\hline Immersion & $\mathbf{8 A}$ & $\mathbf{9 A}$ & $\mathbf{1 0 A}$ & $\mathbf{1 1 A}$ & $\mathbf{1 2 A}$ & 13A & 14A \\
\cline { 2 - 8 } duration (Minutes) & COR (mpy) & COR (mpy) & COR (mpy) & COR (mpy) & COR (mpy) & COR (mpy) & COR (mpy) \\
\hline 5 & 2.87 & 1.82 & 1.80 & 11.00 & 9.12 & 8.18 & 7.97 \\
10 & 3.43 & 2.37 & 2.90 & 7.37 & 8.14 & 7.17 & 6.93 \\
15 & 2.46 & 2.71 & 2.45 & 7.40 & 6.75 & 6.61 & 6.11 \\
20 & 2.26 & 2.45 & 2.99 & 1.26 & 0.97 & 0.91 & 3.91 \\
25 & 3.74 & 2.90 & 2.68 & 1.96 & 2.47 & 2.31 & 2.12 \\
30 & 3.45 & 2.26 & 2.41 & 0.72 & 0.84 & 0.26 & 1.09 \\
35 & 2.16 & 2.53 & 2.50 & 1.46 & 1.15 & 0.55 & 0.63 \\
40 & 2.58 & 2.32 & 2.61 & 0.76 & 0.77 & 0.70 & 0.73 \\
45 & 2.73 & 2.22 & 2.17 & 0.54 & 0.49 & 0.43 & 0.68 \\
50 & 2.58 & 2.48 & 2.15 & 0.53 & 0.41 & 2.87 & 2.96 \\
\hline
\end{tabular}

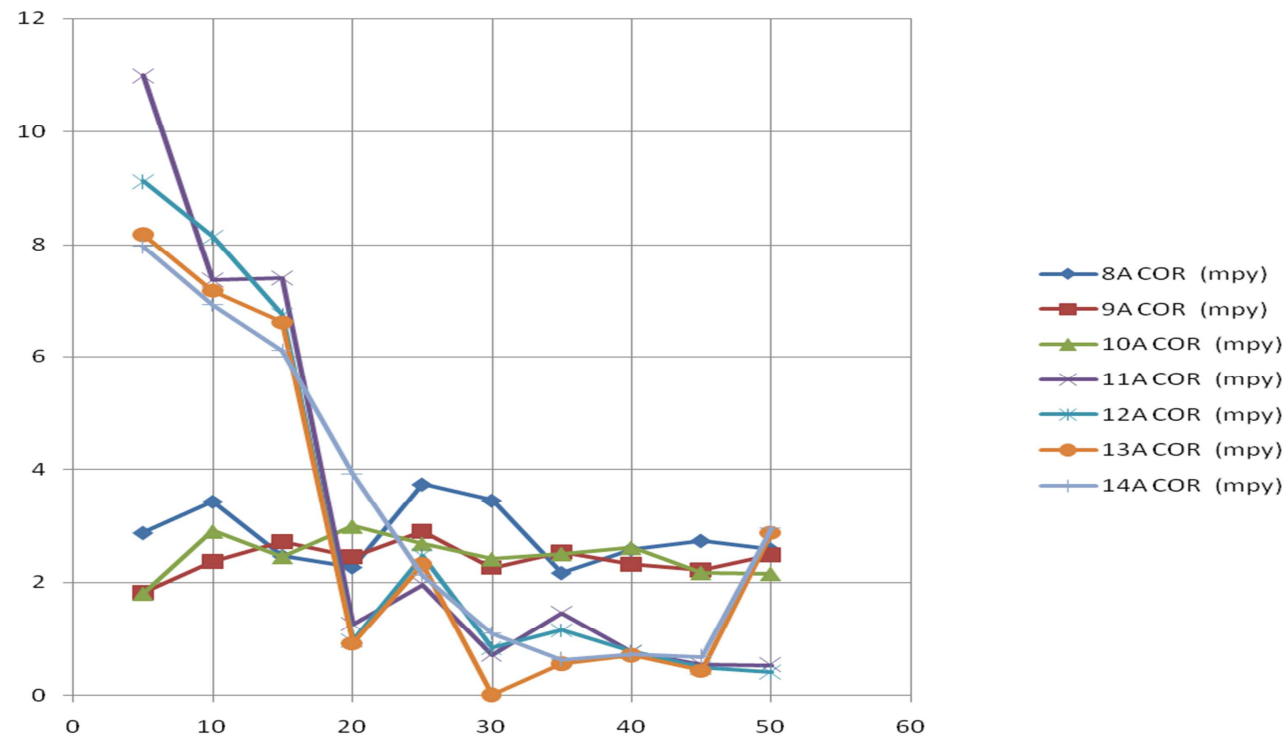

Figure 5. Graphical relationship of immersion duration in oxidizing medium $\left\{\mathrm{H}_{2} \mathrm{SO}_{4}\right\}$ versus corrosion rate (COR) for various samples in Table 3.

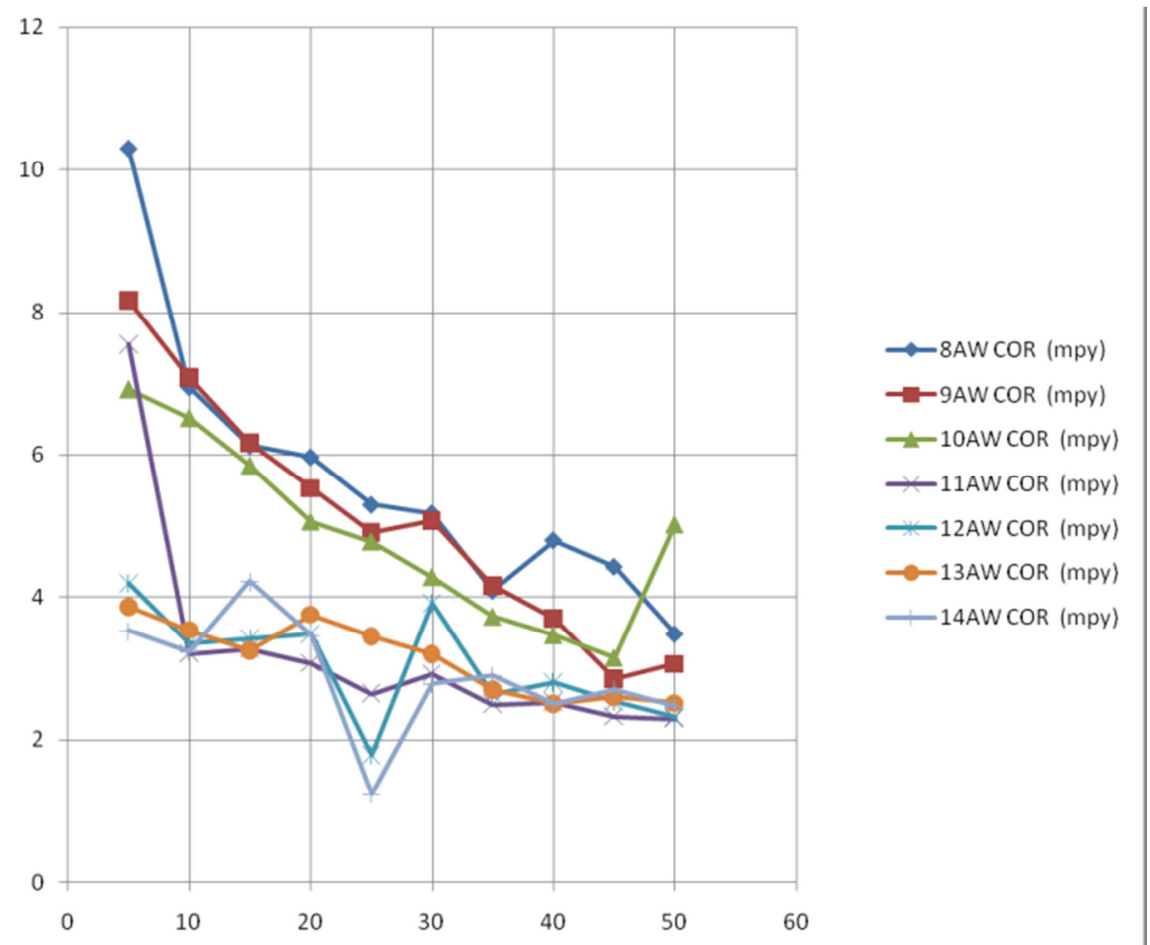

Figure 6. Graphical relationship of immersion duration in oxidizing medium $\left(\mathrm{H}_{2} \mathrm{SO}_{4}\right)$ versus corrosion rate (COR) for various samples in table 4. 
Table 4. Corrosion rate (COR) of unwelded AISI 316 samples $\{8 \mathrm{AW}, 9 \mathrm{AW}, 10 \mathrm{AW}, 11 \mathrm{AW}, 12 \mathrm{AW}, 13 \mathrm{AW}, 14 \mathrm{AW}\}$, soaked at $750^{\circ} \mathrm{C}$ at variable soaking time of 30 , $60,180,300,400,500$ and 600 minutes respectively and immersed in oxidizing medium \{H2SO4\} at variable immersion duration.

\begin{tabular}{llllllll}
\hline Immersion & 8AW & 9AW & 10AW & 11AW & 12AW & 13AW & 14AW \\
\cline { 2 - 7 } duration (Minutes) & COR (mpy) & COR (mpy) & COR (mpy) & COR (mpy) & COR (mpy) & COR (mpy) & COR (mpy) \\
\hline 5 & 10.29 & 8.16 & 6.92 & 7.55 & 4.19 & 3.87 & 3.52 \\
10 & 6.95 & 7.08 & 6.52 & 3.20 & 3.34 & 3.54 & 3.23 \\
15 & 6.13 & 6.17 & 5.85 & 3.27 & 3.41 & 3.25 & 4.22 \\
20 & 5.97 & 5.53 & 5.06 & 3.07 & 3.48 & 3.76 & 3.46 \\
25 & 5.30 & 4.91 & 4.78 & 2.64 & 1.79 & 3.45 & 1.23 \\
30 & 5.18 & 5.07 & 4.28 & 2.92 & 3.91 & 3.20 & 2.78 \\
35 & 4.09 & 4.16 & 3.72 & 2.49 & 2.64 & 2.70 & 2.89 \\
40 & 4.80 & 3.70 & 3.46 & 2.53 & 2.80 & 2.50 & 2.50 \\
45 & 4.43 & 2.85 & 3.14 & 2.32 & 2.53 & 2.60 & 2.70 \\
50 & 3.48 & 3.06 & 5.02 & 2.29 & 2.32 & 2.51 & 2.46 \\
\hline
\end{tabular}

Table 5. Average corrosion rate of AISI 316 samples of unwelded $\{1 \mathrm{~A}, 2 \mathrm{~A}, 3 \mathrm{~A}, 4 \mathrm{~A}, 5 \mathrm{~A}, 6 \mathrm{~A}, 7 \mathrm{~A}\}$ and welded $\{1 \mathrm{AW}, 2 \mathrm{AW}, 3 \mathrm{AW}, 4 \mathrm{AW}, 5 \mathrm{AW}, 6 \mathrm{AW}, 7 \mathrm{AW}\}$, soaked at $750^{\circ} \mathrm{C}$ at variable soaking time of $30,60,180,300,400,500$ and 600 minutes respectively and immersed in non-oxidizing medium (HCL) at variable immersion duration.

\begin{tabular}{llll}
\hline Unwelded 1A-7A & Welded 1AW-7AW & \\
\hline Immersion duration (Minutes) & COR (mpy) \{Average\} & Immersion(Soaking) duration in HCL Time (Mins) & COR (mpy) \{Average\} \\
\hline 5 & 7.82 & 5 & 8.38 \\
10 & 5.00 & 10 & 6.78 \\
15 & 3.20 & 15 & 6.60 \\
20 & 3.32 & 20 & 6.26 \\
25 & 3.12 & 25 & 5.54 \\
30 & 3.19 & 30 & 5.54 \\
35 & 2.85 & 35 & 4.17 \\
40 & 2.66 & 40 & 4.66 \\
45 & 2.91 & 45 & 4.26 \\
50 & 2.54 & 50 & 4.06 \\
\hline
\end{tabular}

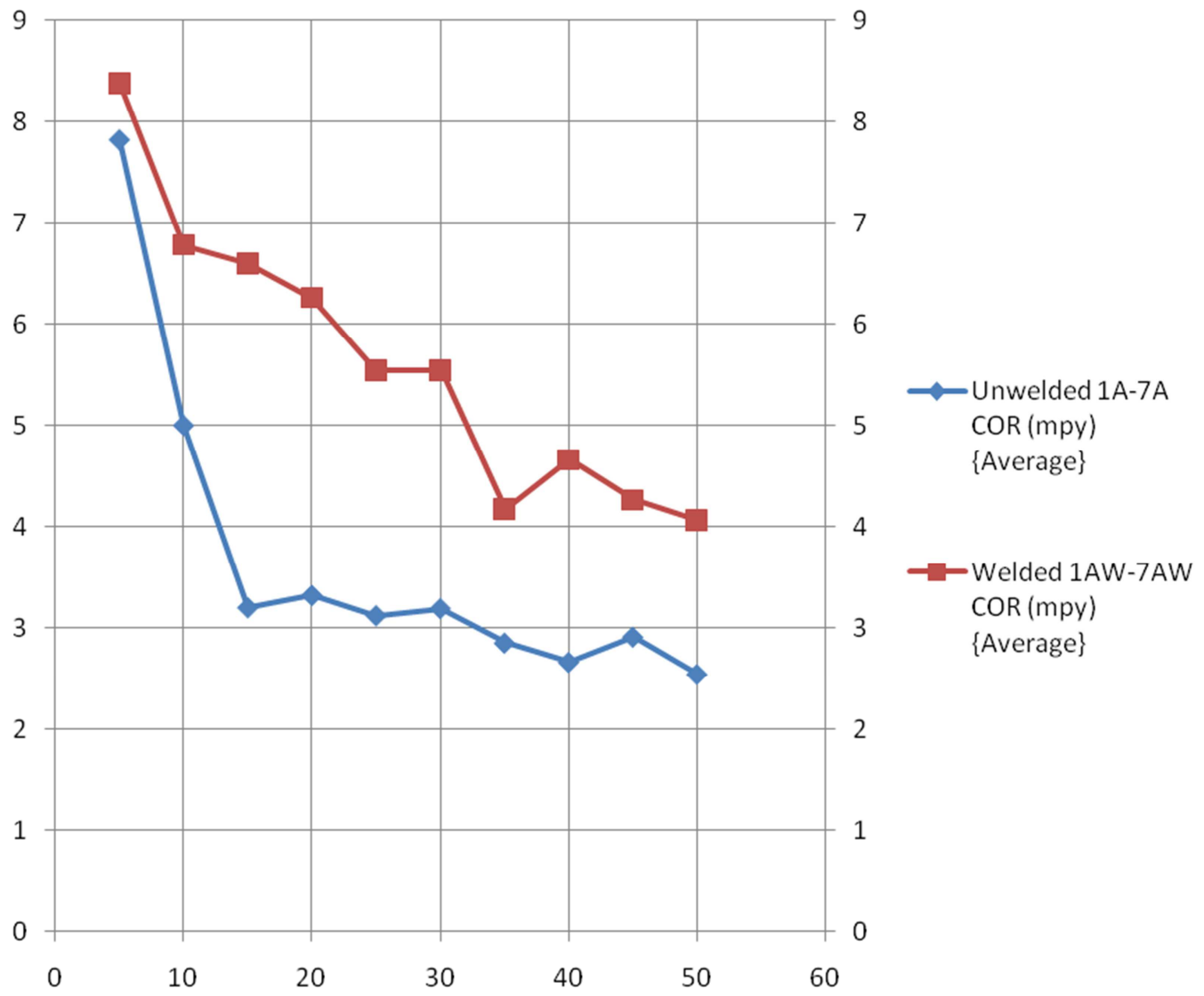

Figure 7. Graphical relationship of immersion duration in non-oxidizing medium (HCL) versus average corrosion rate (COR) for various samples of welded and unwelded as shown in table 5 . 
Table 6. Average corrosion rate of AISI 316 samples of unwelded $\{8 \mathrm{~A}, 9 \mathrm{~A}, 10 \mathrm{~A}, 11 \mathrm{~A}, 12 \mathrm{~A}, 13 \mathrm{~A}, 14 \mathrm{~A}\}$ and welded $\{8 \mathrm{AW}, 9 \mathrm{AW}, 10 \mathrm{AW}, 11 \mathrm{AW}, 12 \mathrm{AW}, 13 \mathrm{AW}$, $14 \mathrm{AW}$, soaked at $750^{\circ} \mathrm{C}$ at variable soaking time of 30,60,180,300, 400, 500 and 600 minutes respectively and immersed in oxidizing medium (H2SO4) at variable immersion duration.

\begin{tabular}{llll}
\hline Unwelded (8A-14A) & & Welded (8AW-14AW) & \\
\hline $\begin{array}{l}\text { Immersion (Soaking) duration in } \\
\text { \{H2SO4\} Time (Mins) }\end{array}$ & COR (mpy) \{Average\} & $\begin{array}{l}\text { Immersion (Soaking) duration in }\{\text { H2SO4\} } \\
\text { Time (Mins) }\end{array}$ & COR (mpy) \{Average\} \\
\hline 5 & 6.11 & 5 & 6.36 \\
10 & 5.47 & 10 & 4.84 \\
15 & 5.00 & 15 & 4.61 \\
20 & 2.11 & 20 & 27.36 \\
25 & 2.60 & 25 & 3.44 \\
30 & 1.68 & 30 & 3.91 \\
35 & 1.57 & 35 & 3.24 \\
40 & 1.50 & 40 & 2.94 \\
45 & 1.32 & 45 & 3.02 \\
50 & 1.20 & 50 & \\
\hline
\end{tabular}

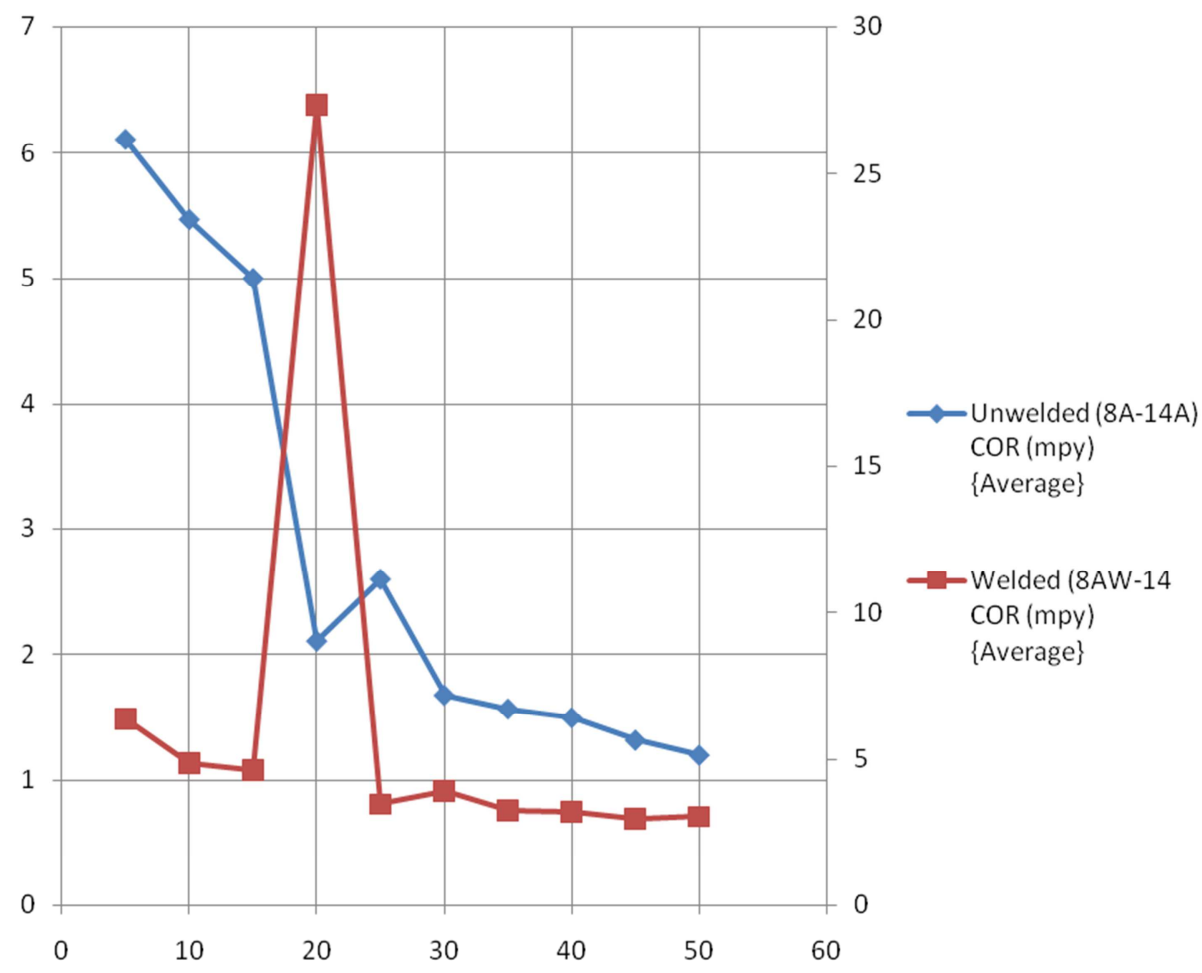

Figure 8. Graphical relationship of immersion duration in oxidizing medium $\left\{\mathrm{H}_{2} \mathrm{SO}_{4}\right\}$ versus average corrosion rate (COR) for various samples of welded and unwelded as shown in table 6.

\section{Discussions}

From table 1 and figure 3 above, sample $4 \mathrm{~A}$ has the highest corrosion rate within five minutes of immersion duration in non-oxidizing medium (HCL); but decreased sharply to $2.72 \mathrm{mpy}$ as immersion time increased up to 15 minutes; then fluctuates gradually as immersion time increases. Corrosion rate of 4A, 5A, 6A, 7A have an initial sharp decreases; but fluctuates gradually at lower corrosion rate as immersion duration increases. 5A has the lowest corrosion rate, while $4 \mathrm{~A}$ has the highest. Careful study showed that corrosion rate of $2 \mathrm{~A}, 3 \mathrm{~A}$ and $5 \mathrm{~A}$ are more stable and decreases at increasing soaking time and immersion duration in HCL. One thing is common in all the samples; the resistance to corrosion increases and sensitivity to fluctuation in corrosion rate decreases as immersion duration/ soaking time is increased. This could be attributed to the positive recovery in the sensitized steel [25-26].

From table 2 and figure 4 above, sample $2 \mathrm{AW}$ has the highest corrosion rate within five minutes of immersion time in non-oxidizing agent (HCL); but decreased sharply as immersion time increases up to 10 minutes; then gradually decreases as immersion time increases. Careful study of the table 2 and the figure 2 below showed that sample 7A become erratic at lower corrosion rate, between 20 and 30 minutes of immersion time; decreasing and increasing sharply at lower corrosion rate. Also corrosion rates of samples 4A, 5A, 6A, 7A are smaller than the corrosion rates of $1 \mathrm{~A}, 2 \mathrm{~A}$ and $3 \mathrm{~A}$, at all immersion duration, but 
significantly corrosion rates of samples 4A, 5A, 6A stably decreases as immersion duration increases. From the table and the graph, one thing is common; corrosion rate tend to decreases with increasing immersion duration /soaking time in the non-oxidizing agent.

From table 3 and figure 5 above, samples 11A, 12A, 13A and 14A have very sharp drop in corrosion rate (from very high to very low corrosion rate), as immersion duration in oxidizing agent $\left(\mathrm{H}_{2} \mathrm{SO}_{4}\right)$ increased up to 30minutes of immersion duration. Samples 8A, 9A, 10A have relatively initial lower corrosion rate than $11 \mathrm{~A}, 12 \mathrm{~A}, 13 \mathrm{~A}$ and $14 \mathrm{~A}$ in the oxidizing agent $\left(\mathrm{H}_{2} \mathrm{SO}_{4}\right)$, but fluctuate at higher corrosion rate, as immersion duration/soaking time increases.

Careful study of the table 3 and the figure 3 , showed that corrosion rate of samples $11 \mathrm{~A}, 12 \mathrm{~A}$, have lower corrosion rate than samples $8 \mathrm{~A}, 9 \mathrm{~A}, 10 \mathrm{~A}$, as immersion duration is increased between 20-50 minutes. Sample 13A has the lowest corrosion rate among the samples at 30minutes. Also, samples $13 \mathrm{~A}$ and 14A have lower corrosion rate than $8 \mathrm{~A}, 9 \mathrm{~A}$, $10 \mathrm{~A}$ between 20-40minutes of immersion duration; but tend to arise sharply as immersion duration increase.

From table 4 and figure 6 above, the corrosion rates of samples 12AW, 13AW and 14AW, fluctuates at a lower corrosion rate than samples 8AW, 9AW and 10AW. Sample $11 \mathrm{AW}$ had sharp corrosion rate decrease, from $7.55 \mathrm{mpy}$ to $3.2 \mathrm{mpy}$ within the first 5 minutes of immersion duration in $\mathrm{H}_{2} \mathrm{SO}_{4}$. Samples 11AW, 12AW 13AW and 14AW fluctuates at a lower corrosion rate than samples $8 \mathrm{AW}, 9 \mathrm{AW}$ and $10 \mathrm{AW}$ between 10-50 minutes of immersion duration in $\mathrm{H}_{2} \mathrm{SO}_{4}$. Careful study of the table 4 and figure 4 showed that Samples 8AW, 9AW and 10AW, tend to decrease steadily as immersion duration/soaking increases, but at a higher corrosion rate than $11 \mathrm{AW}, 12 \mathrm{AW} 13 \mathrm{AW}$ and $14 \mathrm{AW}$.

Careful study of table 5 and figure 7 above, showed that average corrosion rate of the unwelded samples 1A-7A and welded samples $1 \mathrm{AW}-7 \mathrm{AW}$, decreases with increase in immersion duration and soaking time in the non-oxidizing agent of HCL; but the rate of decrease is higher in the unwelded samples than that of the welded samples, as immersion duration and soaking time increases.

Careful study of table 6 and figure 8 above showed that average corrosion rate of the unwelded samples $8 \mathrm{~A}-14 \mathrm{~A}$ decreases with increase in immersion duration /soaking time in the oxidizing agent $\left(\mathrm{H}_{2} \mathrm{SO}_{4}\right)$. However, erratic behaviour is observed in the welded samples $8 \mathrm{AW}-14 \mathrm{AW}$. The average corrosion rate of the samples rose sharply in the oxidizing agent $\left(\mathrm{H}_{2} \mathrm{SO}_{4}\right)$, between 15 and 20 minutes of immersion duration; and decreased sharply almost at the same rate within additional 5 minutes; but generally has a lower corrosion rate than the unwelded samples between 25-50 minutes of immersion duration and variable increasing soaking time.

\section{Conclusions}

From the results and graphical analysis, the following may be concluded: a) Corrosion rates of unwelded and welded samples of AISI 316 decreases as soaking time and immersion duration increases in non-oxidizing medium of HCL.

b) What must have happened? Thermodynamically, when the steels were subjected to intermediate homogenous temperature $[27,28]$ of $750^{\circ} \mathrm{C}$, at variable increasing soaking time, recovery may have ${ }^{\circ}$ Ccurred, from possible presence of Cr-rich alpha prime $\left(\alpha^{\prime}\right)$ precipitates/formation [24, 29], a key material degradation properties that limits its upper service temperature and general mechanical properties.

c) The rate of corrosion rate decrease in hydr ${ }^{\circ} \mathrm{Chloric}$ acid (HCL) medium of the unwelded samples of AISI 316 with increase in immersion duration/ soaking time is greater than that of their welded counterparts at the same constant soaking temperature.

d) The unequilibrium heat cycles, which resulted in complex reactions/phase transformation of the steel (AISI 316), during welding activities sensitized the weldment differently which significantly resulted in different corrosive impacts.

e) Similarly, the unwelded and welded samples of AISI 316 subjected to variable soaking rate and immersion duration in oxidizing medium $\left(\mathrm{H}_{2} \mathrm{SO}_{4}\right)$; have one common characteristic with their corrosion rate decreasing as soaking time and immersion duration increases at constant soaking temperature.

f) However, the welded samples of AISI 316 in oxidizing medium of $\mathrm{H}_{2} \mathrm{SO}_{4}$, experienced erratic behaviour at immersion duration between 15 and 25 minutes. The corrosion rate increased sharply between 15 and 20 minutes of immersion duration and sharply decreased approximately at the same rate within additional 5minutes of immersion duration. Between 2550 minutes, the corrosion rate of welded samples of AISI 316 is lower in the oxidizing medium $\left(\mathrm{H}_{2} \mathrm{SO}_{4}\right)$ than that of their unwelded counterpart at the same immersion duration and soaking time.

g) Finally, the differences in sensitization of the steel weldment and the unwelded counterpart significantly affected their reaction in oxidizing and non-oxidizing media which led to the differences in their corrosion rates. Recovery during soaking time significantly contributed to the improved corrosion resistance of the steel in both oxidizing and non oxidizing environment.

\section{References}

[1] Silas Ezedinma Agbokwor, Simeon Ikechukwu Neife: Investigation of the Effects of Soaking Time on the Properties of Stainless Steel: American Journal of Mechanical and Materials Engineering. Vol. 3, No. 3, 2019, pp. 47-52. doi: 10.11648/j.ajmme.20190303.11.

[2] Pierre R. Roberge: Corrosion Basics-An Introduction, Second Ed. (Houston, TX: NACE International, 2006), pp. 2122. 
[3] National Corrosion Service (NCS) Publication UK. Guides to good practice in corrosion control. (www.npl.co.uk), 2000.

[4] P. T Jakosbsen and E Maahn: Temperature and potential dependence of crevice corrosion of AISI 316 stainless steel. Corrosion Science, 2001, 43 [p 1693-1709].

[5] Rondelli, G.; Vicentini, B. Susceptibility of highly alloyed austenitic stainless steels to caustic stress corrosion cracking. Mater. Corros. 2002, 53, 813-819.

[6] Rondelli, G.; Vicentini, B.; Sivieri, E. Stress corrosion cracking of stainless steels in high temperature caustic solutions. Corros. Sci. 1997, 39, 1037-1049.

[7] Parnian, N. Failure analysis of austenitic stainless steel tubes in a gas fired steam heater. Mater. Des. 2012, 36, 788-795.

[8] Betova, I.; Bojinov, M.; Hyökyvirta, O.; Saario, T. Effect of sulphide on the corrosion behaviour of AISI 316L stainless steel and its constituent elements in simulated kraft digester conditions. Corrosion Science. 2010, 52, 1499-1507.

[9] Chasse, K.; Raji, S.; Singh, P. Effect of chloride ions on corrosion and stress corrosion cracking of duplex stainless steels in hot alkaline-sulfide solutions. Corrosion 2012, 68, 932-949.

[10] Mills WJ. Fracture toughness of type 304 and 316 stainless steels and their welds. Int. Mater. Rev. 1997; 42:45-82. doi: 10.1179/imr.1997.42.2.45.

[11] Frankel, G., et al. $\mathrm{L}^{\circ}$ Calized corrosion: general discussion; Faraday Discussions. 2015180 (0): P. 381-414.

[12] Zheng S, Shibata T, Haruna T: Corrosion Science Journal, 2005, 47, 1049-1061.

[13] Seifedine, K (2008): European Journal of Scientific Research, ISSN 1450-216X Vol. 22 No. 4, 2008, 508-516.

[14] Pitting Corrosion," NACE International, http://www.nace.org/Pitting-Corrosion (September 28, 2015).

[15] Chen YY, Chou LB, Shih HC, Mater. Chem. Phy., 2006, 96, 37-49.

[16] G. H. $\mathrm{K}^{\circ} \mathrm{Ch}$, et al., "Corrosion Costs and Preventive Strategies in the United States," Federal Highway Administration, FHWA-RD-01-156, March 2002.

[17] Kumar, S.; Shahi, A. S. On the influence of welding stainless steel on microstructural development and mechanical performance. Mater. Manuf. Pr $^{\circ}$ Cess. 2014, 29, 894-902.

[18] Pramar S: Welding metallurgy 2nd Ed. \{(2003) [New Jersey]\}.

[19] Sindou Kou (2003). Welding Metallurgy. 2nd Ed. A John Wiley and Sons, INC. Publication. New Jersey.

[20] F. Haraszti: The bases of corrosion investigation EME press, Múszaki Tudományos Füzetek 21 , Cluj $\mathrm{Nap}^{\circ} \mathrm{Ca}\{2016\}$ pp. 185-188.

[21] F. Haraszti: Corrosion investigation of steel samples EME press, Múszaki Tudományos Füzetek 21, Cluj Nap ${ }^{\circ} \mathrm{Ca}\{2016\}$ pp. 189-192.

[22] Reti T, Kovacs T: A phenomenological method for the prediction of damage accumulation $\mathrm{pr}^{\circ} \mathrm{Cesses}$ under varying external conditions In: Materials Science Forum, 414-415, $\{2003\}$ pp. $317-322$.

[23] Parvathavarthini N, Dayal RK, Khatak HS, Shankar V, Journal Nuclear Matererial, 2006, 355, 68-82.

[24] T. Kovács, L. Kuzsella: High Energy Rate Forming Induced Phase Transition in austenitic steel; Journal of Physics Conference-Series 790: Paper 012039. 5 \{2017\}'.

[25] M. Dománkova, et al: The microstructure evolution and its effect on corrosion properties of $18 \mathrm{Cr}-12 \mathrm{Ni}-2$, 5Mo Steel, annealed at $500-900^{\circ} \mathrm{C}$, Acta Polytechnica Hungarica, 11 $3\{2014\}$ pp. $125-137$.

[26] Li SL, Zhang HL, Wang YL, Li SX, Zheng K, Xue F, Wang $\mathrm{XT}$. Annealing induced recovery of long-term thermal aging embrittlement in a duplex stainless steel. Material Science Engineering A 2013; 564:85-91.

[27] Elsariti, S. M. Behaviour of stress corrosion cracking of austenitic stainless steels in sodium chloride solutions. $\operatorname{Pr}^{\circ}$ Cedia Eng. 2013, 53, 650-654.

[28] Kuroda T, Matsuda F. Role of secondary austenite on corrosion and stress corrosion cracking of sensitized duplex stainless steel weldment, (metallurgy \& weldability). Trans JWRI 1994; 23 (2): 205-11. V. Shamanth, K. S. Ravishankar / Results in Physics 5 (2015) 297-303 303.

[29] Newman, R. C. 2001 W. R. Whitney award lecture: understanding the corrosion of stainless steel; Corrosion 2001. 57 (12): P. 1030-1041. 